\title{
Paleo Agulhas rings enter the subtropical gyre during the penultimate deglaciation
}

\author{
P. Scussolini ${ }^{1,2}$, E. van Sebille ${ }^{3}$, and J. V. Durgadoo ${ }^{4}$ \\ ${ }^{1}$ Earth and Climate Group, Vrije Universiteit, Amsterdam, the Netherlands \\ ${ }^{2}$ The Bjerknes Centre for Climate Research, Uni Research, Bergen, Norway \\ ${ }^{3}$ Climate Change Research Centre \& ARC Centre of Excellence for Climate System Science, \\ University of New South Wales, Sydney, Australia \\ ${ }^{4}$ GEOMAR Helmholtz Centre for Ocean Research Kiel, Kiel, Germany
}

Correspondence to: P. Scussolini (p.scussolini@vu.nl)

Received: 17 March 2013 - Published in Clim. Past Discuss.: 11 April 2013

Revised: 15 October 2013 - Accepted: 1 November 2013 - Published: 25 November 2013

\begin{abstract}
A maximum in the strength of Agulhas leakage has been registered at the interface between the Indian and South Atlantic oceans during glacial Termination II (T-II). This presumably transported the salt and heat necessary for maintaining the Atlantic circulation at rates similar to the present day. However, it was never shown whether these waters were effectively incorporated into the South Atlantic gyre, or whether they retroflected into the Indian and/or Southern oceans. To resolve this question, we investigate the presence of paleo Agulhas rings from a sediment core on the central Walvis Ridge, almost $1800 \mathrm{~km}$ farther into the Atlantic Basin than previously studied. Analysis of a $60 \mathrm{yr}$ data set from the global-nested INALT01 model allows us to relate density perturbations at the depth of the thermocline to the passage of individual rings over the core site. Using this relation from the numerical model as the basis for a proxy, we generate a time series of variability of individual Globorotalia truncatulinoides $\delta^{18} \mathrm{O}$. We reveal high levels of pycnocline depth variability at the site, suggesting enhanced numbers of Agulhas rings moving into the South Atlantic Gyre around T-II. Our record closely follows the published quantifications of Agulhas leakage from the east of the Cape Basin, and thus shows that Indian Ocean waters entered the South Atlantic circulation. This provides crucial support for the view of a prominent role of the Agulhas leakage in the shift from a glacial to an interglacial mode of the Atlantic circulation.
\end{abstract}

\section{Introduction}

A transport of upper water masses takes place around the tip of South Africa, where the Agulhas retroflection spills Indian Ocean waters into the South Atlantic (Lutjeharms, 2006; Beal et al., 2011, and references therein). This Agulhas leakage (hereafter AL) is an important component of the salt and heat transport into the Atlantic Ocean (Gordon et al., 1992; Weijer et al., 2001; Dong et al., 2011). The recipient of this transfer is the Cape Basin, in which a host of complex and turbulent phenomena occur (e.g. Olsen and Evans, 1986; Boebel et al., 2003; Doglioli et al., 2006).

Waters of Indian Ocean origin travel across the Cape Basin in a variety of forms and shapes. These can be broadly characterized as anticyclonic (e.g. Schouten et al., 2000), cyclonic eddies (Hall and Lutjeharms, 2011), and filaments (or streamers, or liners) wound between the spinning eddies (Lutjeharms and Cooper, 1996; Treguier et al., 2003). It is not yet clear how the AL is partitioned between these transport features (e.g. Doglioli et al., 2006; van Sebille et al., 2010a), but a significant part of the AL is in the form of rings (van Sebille et al., 2010a; Dencausse et al., 2010).

\subsection{Agulhas rings and the thermocline}

Agulhas rings have been described as quite regular features of mostly barotropic flow, and as the greatest and most energetic mesoscale eddies in the world (Clement and Gordon, 1995; Olson and Evans, 1986). Approximately 6 rings are spawned per year and they reach, though then very 
diminished, as far as $40^{\circ} \mathrm{W}$ (Byrne et al., 1995). Their most conspicuous characteristic, upon entrance into the Cape Basin, is the dramatic depression they impose on isotherms, isopycnals and isohalines (Arhan et al., 2011; Souza et al., 2011; Giulivi and Gordon, 2006), as they transport water that is much warmer and saltier than the surroundings from the sub-surface to at least $\sim 1000 \mathrm{~m}$ depth (van Aken et al., 2003).

It is understood indeed that the bulk of the AL happens below the surface, at the depths of the thermocline (Donners and Drijfhout, 2004; Doglioli et al., 2006; van Sebille et al., 2010b). Observations of Gordon et al. (1992) show that across the Cape Basin thermocline, two thirds of the water between the $9{ }^{\circ} \mathrm{C}$ and $14^{\circ} \mathrm{C}$ isotherms is of Indian Ocean origin. The observational study of Richardson (2007) reveals that while surface drifters adopt more northerly trajectories closer to the Benguela Current, floats at $\sim 800 \mathrm{~m}$ travel right over the central Walvis Ridge. Souza et al. (2011) maintain that the largest heat perturbation introduced by Agulhas rings occurs at depths between 200 and $600 \mathrm{~m}$.

\subsection{In search of a missing paleo link}

In the last decades, researchers have come to consider the $\mathrm{AL}$ mechanism to play an important role in the changes in heat and salt transports into the Atlantic Ocean during Pleistocene climate shifts (e.g. Berger and Wefer, 1996). The hypothesis of a reduced Indian to Atlantic transfer during glacial periods is compatible with the northward shift of the oceanographic fronts south of Africa (Hays et al., 1976; Bé and Duplessy, 1976; Bard and Rickaby, 2009).

While paleoceanographic research on marine sediments has made a convincing case that the Agulhas Current (Hutson, 1980) and AL (Franzese et al., 2006) were reduced during glacial times, most of the evidence was gathered in the easternmost part of the Cape Basin, depicting intense presence of Indian Ocean waters during glacial terminations (Flores et al., 1999; Peeters et al., 2004; Marino et al., 2013) (Figs. 1 and 2b). As modern observations show, a significant fraction of Agulhas rings that reach the Cape Basin successively bend either south, to the Southern Ocean, or rejoin the Agulhas retroflection (Dencausse et al., 2010; Arhan et al., 2011). These rings have a much smaller impact on the transport of salt and heat into the Atlantic Ocean than those that cross the Walvis Ridge.

Therefore, a key question still remains: were the observed maxima in AL eventually incorporated into the South Atlantic gyre, thus forming the waters that could subsequently cross the Equator through the North Brazil Current? To postulate that enhanced AL did result in an increased salt and heat flux into the Atlantic requires the establishment of this paleo connection between the eastern Cape Basin and the South Atlantic circulation.

Here we test this case for the penultimate deglaciation (T-II). The reason for this choice of interval is the inten-

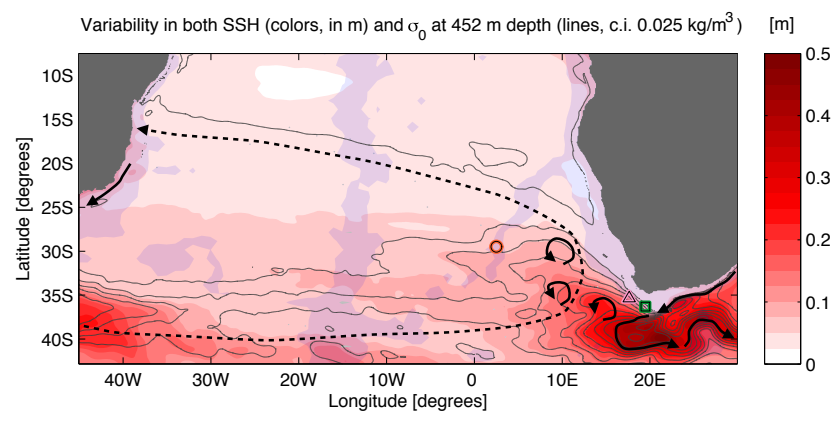

Fig. 1. Map of the southeast Atlantic, with location of the core studied here (orange circle), of the Cape Basin record (pink triangle) of Peeters et al. (2004), and of the Agulhas Bank Splice (green square) of Martínez-Méndez et al. (2010). Also indicated are contoured variabilities of both SSH (colours) and of $\sigma_{\theta}$ at the $452 \mathrm{~m}$ depth model level (lines) over the basin, in the INALT01 model (see Methods). The blue arrows show the schematics of the water currents discussed here: Agulhas Current, Agulhas rings and cyclones, and South Atlantic Gyre circulation.

sity and sharpness of the AL release that characterizes this climatic transition, as attested by distinguished peaks in existing Pleistocene reconstructions (Peeters et al., 2004; Martínez-Méndez et al., 2010) (Fig. 2b). Also, marked changes during T-II were recently revealed in AL temperature and salinity (Marino et al., 2013) and in southeast Atlantic stratification (Scussolini and Peeters, 2013), warranting further investigation.

Our hypothesis is rationalized as follows. Regardless of the form it assumes - either rings or filaments - the AL introduces anomalies in the temperature and salinity fields of the South Atlantic subtropical gyre. It is of high interest to both the paleoclimatology and the modern oceanography communities to know whether such perturbations were present over the central Walvis Ridge, almost $1800 \mathrm{~km}$ further downstream into the Atlantic Ocean, and with which intensity, under different climatic frameworks.

Modern analytic techniques enable us to investigate such anomalies, by means of geochemical analysis of microfossils from marine sediment. By selecting the appropriate species of planktic foraminifer, we aim to target water masses at the depth of the thermocline, where variability due to $\mathrm{AL}$ should be maximal (Souza et al., 2011). Recently, paleoceanographic research has started to employ the oxygen isotope composition $\left(\delta^{18} \mathrm{O}\right)$ of individual foraminifera, to address questions related to variability. For instance, Billups and Spero (1995) and Ganssen et al. (2011) used single-shell analyses to unravel the range of hydrographic conditions in the equatorial Atlantic and in the Arabian Sea, respectively, while Koutavas et al. (2006) and Leduc et al. (2009) applied the approach to capture ENSO extremes in the Eastern Equatorial Pacific. A review of this type of analysis, and a rigorous statistical assessment of its potential to capture 


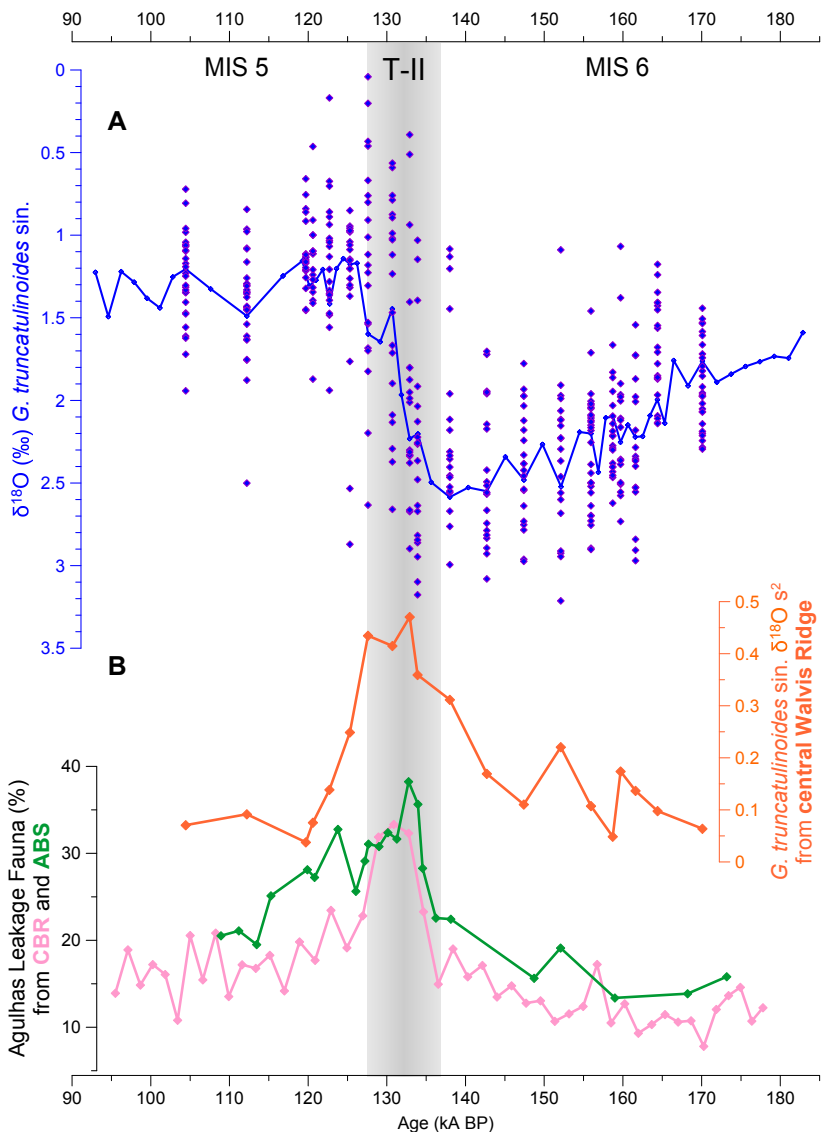

Fig. 2. (A): $\delta^{18} \mathrm{O}$ of $G$. truncatulinoides sin. individuals (blue diamonds) and bulk analysis (blue line, Scussolini and Peeters, 2013). (B): corrected sample $\delta^{18} \mathrm{O}$ variance (orange, see Methods); estimation of AL from the Cape Basin record (CBR, Peeters et al., 2004) (pink), and from the Agulhas Bank Splice (ABS, Martínez-Méndez et al., 2010) (green).

paleoceanographic variability originating from ENSO, were recently provided by Thirumalai et al. (2013).

\subsection{Rings path and core selection}

The path undertaken by Agulhas rings has been the focus of many studies (e.g. Olson and Evans, 1986; Dencausse et al., 2010; Schouten et al., 2000). The SAVE 4 section in the years 1989-1990 encountered two Agulhas rings at the central Walvis Ridge, at about $30^{\circ} \mathrm{S}$ (Gordon et al., 1992). Satellite data (Gordon and Haxby, 1990; Boebel et al., 2003) make it clear that this location is in the full trajectory of rings. Generally, topography seems to be decisive to the displacement of eddies in the Cape Basin (Matano and Beier, 2003; Boebel et al., 2003), and some of the deep canyons in this ridge possibly steer the passage of rings (Byrne et al., 1995; Dencausse et al., 2010; van Sebille et al., 2012). This body of knowledge led us to choose the central Walvis Ridge as an appropriate setting to test our hypothesis.
In addition, we use a high-resolution global ocean circulation model to illustrate the aptitude of our sediment core, and of our foraminifera taxon, to capture the anomalous density expression that results from the passage of Agulhas rings in the present climate.

\section{Methods}

\subsection{Isotope analysis}

We conducted analysis on core 64PE-174P13, retrieved from the central Walvis Ridge $\left(29^{\circ} 45.71^{\prime} \mathrm{S}, 2^{\circ} 24.10^{\prime} \mathrm{E}\right)$ at a depth of $2912 \mathrm{~m}$ (Fig. 1). From it we selected 18 sediment samples that span $\sim 70000$ years (ka) between Marine Isotope Stage (MIS) 6 and 5, based on the stratigraphy of Scussolini and Peeters (2013), which is anchored to the LR04 marine isotope stack (Lisiecki and Raymo, 2005). Additionally, we selected two samples, from the core top and from $2 \mathrm{~cm}$ in the sediment, representative of near-modern conditions. For each sample, between 18 and 30 specimens of Globorotalia truncatulinoides sinistral (left-coiling variety) were picked from size fraction $250-300 \mu \mathrm{m}$, to constrain the depth of calcification. We selected this taxon due to its extensively studied depth habitat (e.g. Lohmann and Schweitzer, 1990; Mulitza et al., 1997; Mortyn and Charles, 2003; LeGrande et al., 2004). Lončarić et al. (2006) report that the calcification depth of this species in our region extends down to $\sim 400 \mathrm{~m}$; other researchers estimated its depth as reaching $600 \mathrm{~m}$ (Erez and Honjo, 1981) and beyond (Hemleben et al., 1985). The choice of the sinistral variety was mainly due to its regular availability across the interval, testifying to its endemicity (and necessary to perform a sufficient number of individual measurements), and to its ecological preference for a deep thermocline (Lohmann and Schweitzer, 1990). Scussolini and Peeters (2013), confronting $\delta^{18} \mathrm{O}$ values from core top specimens, quantified the habitat depth of the fossil specimens around $500 \mathrm{~m}$. These controls imply that $G$. truncatulinoides $\sin$. befits our objective to target the thermocline. A total of 478 isotopic measurements on individual shells were performed at the Vrije Universiteit, Amsterdam, with methods described in Scussolini and Peeters (2013). The average reproducibility on external standards was better than $0.10 \%$.

Since we are specifically interested in assessing the variability between measurements within samples, it is essential that the typical inter-run fluctuations in instrumental precision do not bias the estimation. For this reason, we corrected the variance of foraminiferal $\delta^{18} \mathrm{O}$ by subtracting that of external calcite standards measured in the same sequence, as recommended by Killingley et al. (1981) (Table 1).

\subsection{Model data set}

In order to assess the relevance of our core site in recording density anomalies associated with Agulhas rings, we employed the INALT01 model (Durgadoo et al., 2013). This 
Table 1. Result of G. truncatulinoides sin. individual isotope measurements, and estimation of sample variability, with the respective correction (see Methods).

\begin{tabular}{cccccc}
\hline $\begin{array}{c}\text { Sample } \\
\text { depth } \\
(\mathrm{cm})\end{array}$ & $\begin{array}{c}\text { Age } \\
(\mathrm{ka} \mathrm{BP})\end{array}$ & $\begin{array}{c}\mathrm{N} \\
\text { specimens }\end{array}$ & $\begin{array}{c}\text { Instrument } \\
\mathrm{s}^{2}\end{array}$ & $\begin{array}{c}\text { Sample } \\
\mathrm{s}^{2}\end{array}$ & $\begin{array}{c}\text { Corrected } \\
\mathrm{s}^{2}\end{array}$ \\
\hline 0 & $\sim 0$ & 28 & 0.025 & 0.350 & 0.325 \\
2 & 2.0 & 18 & 0.003 & 0.573 & 0.570 \\
120 & 104.4 & 29 & 0.004 & 0.074 & 0.070 \\
124 & 112.2 & 28 & 0.015 & 0.106 & 0.091 \\
129 & 119.7 & 19 & 0.009 & 0.047 & 0.038 \\
131 & 120.6 & 17 & 0.012 & 0.087 & 0.075 \\
136 & 122.7 & 21 & 0.003 & 0.142 & 0.139 \\
142 & 125.3 & 20 & 0.025 & 0.274 & 0.249 \\
146 & 127.6 & 20 & 0.006 & 0.440 & 0.434 \\
150 & 130.7 & 20 & 0.006 & 0.421 & 0.415 \\
154 & 132.9 & 19 & 0.012 & 0.482 & 0.470 \\
156 & 133.9 & 20 & 0.009 & 0.368 & 0.359 \\
160 & 138.0 & 19 & 0.009 & 0.320 & 0.311 \\
164 & 142.7 & 20 & 0.009 & 0.178 & 0.169 \\
168 & 147.4 & 21 & 0.009 & 0.119 & 0.110 \\
172 & 152.1 & 20 & 0.006 & 0.226 & 0.220 \\
176 & 155.9 & 30 & 0.015 & 0.122 & 0.107 \\
182 & 158.7 & 20 & 0.012 & 0.061 & 0.049 \\
184 & 159.7 & 18 & 0.009 & 0.183 & 0.174 \\
188 & 161.6 & 19 & 0.025 & 0.162 & 0.137 \\
194 & 164.4 & 21 & 0.003 & 0.101 & 0.098 \\
202 & 170.1 & 28 & 0.004 & 0.067 & 0.063 \\
\hline & & & & & \\
\hline
\end{tabular}

model configuration, based on the NEMO (v3.1.1, Madec, 2008) code, is a high-resolution model of the greater Agulhas region, nested within a half-degree global ocean model. At a $1 / 10^{\circ}$ horizontal resolution, INALT01's nest domain spans the entire South Atlantic including the tropics, between $70^{\circ} \mathrm{W}-70^{\circ} \mathrm{E}$ and $50^{\circ} \mathrm{S}-8^{\circ} \mathrm{N}$. In the vertical, INALT01 has $46 z$ levels: 10 levels in the top $100 \mathrm{~m}$ and a maximum of $250 \mathrm{~m}$ resolution at depth. The model has been shown to represent the known variability of the greater Agulhas system, including a realistic reproduction of the pathways of Agulhas rings (Durgadoo et al., 2013). For the analysis, 60 yr (19482007) of data from the hind-cast experiment were used.

\section{Results}

\subsection{Variability of G. truncatulinoides individuals}

The individual $\delta^{18} \mathrm{O}$ values of $G$. truncatulinoides show inter-sample differences in their distribution (Fig. 2a). Their average for each sample is overall not statistically different from the corresponding values from bulk measurements, i.e. many specimens analysed together, from Scussolini and Peeters (2013) (Fig. 2a), yielding $p=0.51$ on the $t$-test for paired samples.

The corrected variance of samples changes along the transition from MIS 6 to 5 (Table 1; Fig. 2b). It increases from $\sim 145 \mathrm{ka}$ to $\sim 130 \mathrm{ka}$ before present $(\mathrm{BP})$, hence returning more rapidly to levels similar to those of full MIS 6 at $\sim 123 \mathrm{ka} \mathrm{BP}$, after which it remains stable for at least $20 \mathrm{ky}$. Notably, the $\delta^{18} \mathrm{O}$ values of the individual foraminifera show a somewhat bimodal distribution in samples at 142.7, 138, $133.9,132.9$ and $130.7 \mathrm{kaBP}$. The values of the two nearmodern samples are within range of those from early MIS 5 (Table 1), with the most recent being lower than that at $\sim 2 \mathrm{kaBP}$. This confirms that, as in the penultimate cycle, variability decreases from the beginning of the interglacial.

\subsection{Effect of Agulhas rings on the central Walvis Ridge water column}

Analysis of the INALT01 time series for the South Atlantic basin shows that the variability of sea surface height (SSH), which is a proxy for Agulhas rings (van Sebille et al., 2012), and of potential seawater density $\left(\sigma_{\theta}\right)$ in the thermocline at $452 \mathrm{~m}$ depth, are strongly related (Fig. 1). The highest variabilities at both the sea surface and at $452 \mathrm{~m}$ are found south of Africa, in the Agulhas retroflection. From that retroflection area at $20^{\circ} \mathrm{E}$, high regions of variability extend northwestward into the Cape Basin. Today, the core location is found on the equator-ward flank of the ridge of both high sea surface height variability, as well as high variability in density.

The $60 \mathrm{yr}$ model data set allows us to describe the temporal variability induced by individual Agulhas ring crossings at our core location (Fig. 3d). In the model layer at $452 \mathrm{~m}$, rings are characterized by peaks of temperature and salinity, and by troughs of density (see for example the ring on 24 January 1960 in Fig. 3a, and the associated effects on properties in Fig. 3d). It is important to note that the effect of temperature overrides that of salinity in determining density within a ring, in agreement with the observations of Giulivi and Gordon (2006) and Arhan et al. (2011).

We can attribute the largest density troughs to Agulhas rings that fully overshadow the core setting (Fig. 3a), and the minor ones to ring flanks moving over it (Fig. 3c). A Fourier analysis of the sea surface height in INALT01 on the site location reveals a clear annual frequency, but also smaller peaks at periods between 150 and 200 days (not shown). It is hence possible to ascertain that out of the roughly six Agulhas rings typically released per year, core 64PE-174P13 presently captures on average one to two full rings, plus a small number of ring flanks.

\section{Discussion}

The model data (Figs. 1 and 3) clearly show that there is a direct relation between the Agulhas rings passing over the core site and variability in density at the depths where $G$. truncatulinoides records its $\delta^{18} \mathrm{O}$. However, both the paleo and model records demand some consideration. 


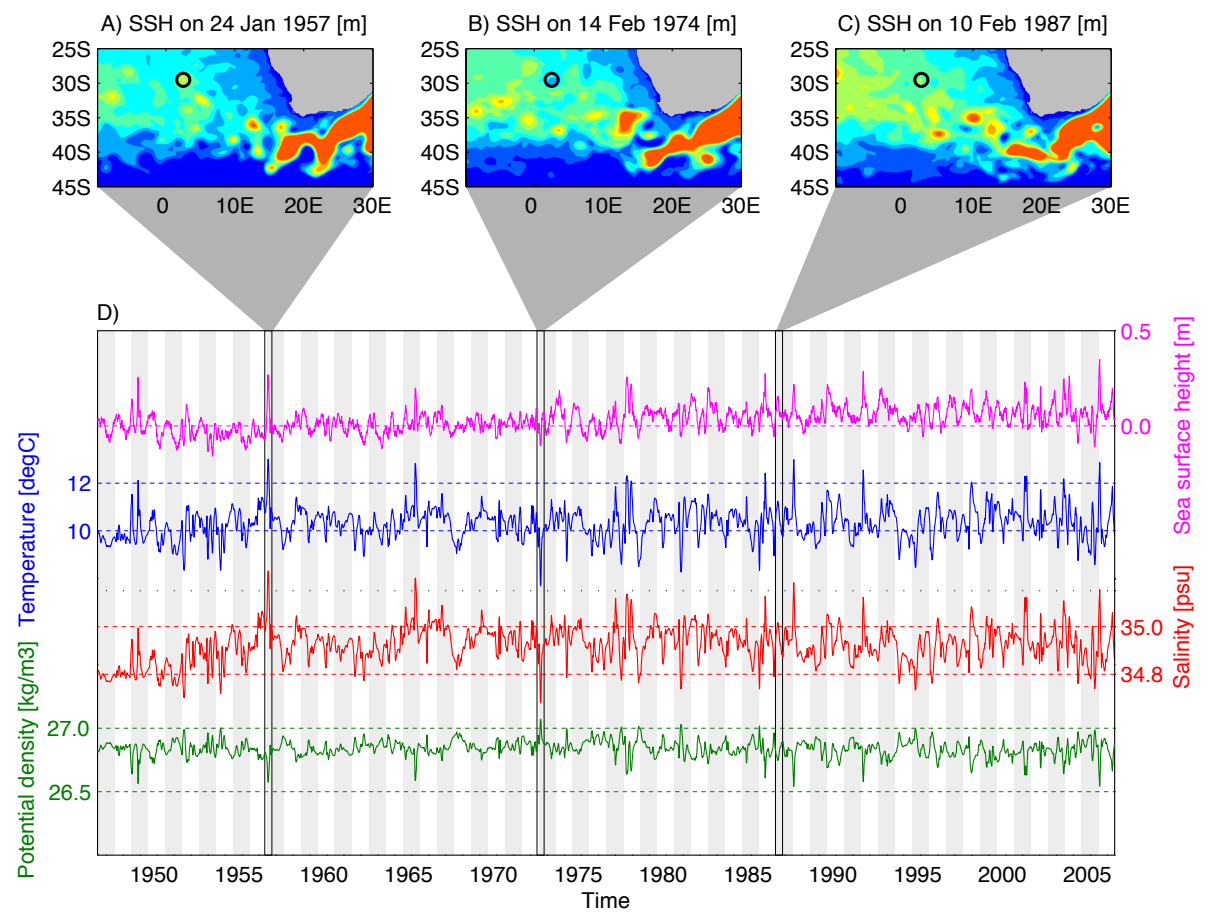

Fig. 3. Analysis of model INALT01 output. (A), (B), and (C): SSH maps showing the position of Agulhas rings with respect to the core location, in three selected situations recurring in the time series (D) of SSH, temperature, salinity and density at $452 \mathrm{~m}$, for the period 1948 2007. (A): full overlap with an Agulhas ring (SSH peak); (B): overlap with a cyclone (trough); (C): partial overlap with an Agulhas ring (small perturbation in the series).

Since we have generated a record of foraminifera $\delta^{18} \mathrm{O}$ variability across a period of shifting values, it is necessary to examine the role that bioturbation potentially plays in it, since its effect might overlap with that of water column perturbations from the AL. To understand the extent of mixing, we take into consideration other independent sedimentological features of core 64PE-174P13, as obtained from additional analyses.

At T-II, the isotope curve of bulk $\delta^{18} \mathrm{O}$ measurements (Scussolini and Peeters, 2013) (Fig. 2a) exhibits a rather large change in values, of $\sim 1.46 \%$, more than observed in a coeval planktic record from the southeast Atlantic, whose multi-centennial detail suggests negligible mixing (Marino et al., 2013). Several other sharp shifts are evident in other parts of the curve of G. truncatulinoides and in that of Globigerinoides ruber (Scussolini and Peeters, 2013). In particular, the latter species shows an abrupt shift in values at T-II, with $0.57 \%$ o change in only $2 \mathrm{~cm}(154$ to $156 \mathrm{~cm})$ (Fig. 4a), and a very constrained spread of measurement repeats $(s<0.08 \% o)$. Furthermore, because we deem G. ruber to be less susceptible to the influence of Agulhas rings, due to its shallower habitat depth, we selected two samples close to this prominent shift, and performed $\delta^{18} \mathrm{O}$ measurements on a single specimen of this species. We observed that closer to the isotopic shift, variability is clearly lower than further from it (Fig. 4b), contrary to what had been expected from the effect of bioturbation. Another aspect is the timing of the T-II shift, which differs between $G$. truncatulinoides and $G$. ruber, a phenomenon that is likely better explained through the differential effect of temperature/salinity rather than selective bioturbation (Bard, 2001). The spread of bulk measurement repeats is also a reflection of the variability inherent in a sample and, given pronounced mixing, should be higher at times of $\delta^{18} \mathrm{O}$ shift. Variability of repeats over the past 460 ka (Scussolini and Peeters, 2013) shows that, while G. truncatulinoides' repeats are generally more divergent at terminations, in agreement with our individual analyses, this is not the case for surface-dwelling G. ruber. Then, X-ray fluorescence profiles portray sharp variations in the content of some elements, close to the interval characterized by the variability peak (Fig. 4c). Lastly, the core shows intervals with distinct colour laminations: regardless of the fact that these are not visible for the T-II interval, they suggest a setting with a relatively undisturbed ocean floor. This is to be expected given the oligotrophic character of the location (Lončaric et al., 2007), as low food supply anti-correlates with the thickness of sediment mixed layer (Trauth et al., 1997; Smith and Rabouille, 2002).

The ensemble of these properties of the sedimentological material is not reconcilable with prominent mixing, and we regard it as evidence that bioturbative processes alone cannot explain the observed variability peak. Therefore, the 


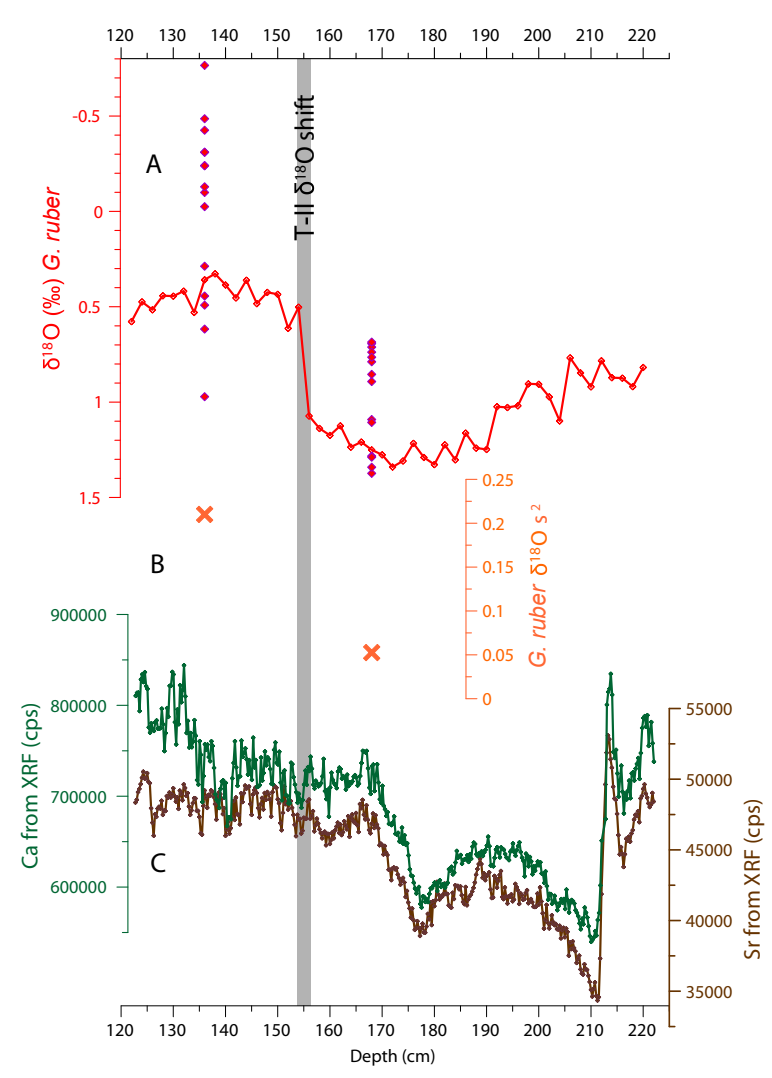

Fig. 4. Sedimentological features pointing to a limited role of bioturbation. (A): $\delta^{18} \mathrm{O}$ of $G$. ruber individuals (purple diamonds) and bulk analysis (red line, Scussolini and Peeters, 2013). (B): corrected sample $\delta^{18} \mathrm{O}$ variance (orange, see Methods). (C): Calcium and strontium abundance from X-ray fluorescence analysis (expressed in counts per second).

phenomenon of increased variability, in such a fully pelagic setting, directly invokes the passage of perturbatory bodies in a field of relatively stable hydrographic conditions.

Inasmuch as foraminiferal $\delta^{18} \mathrm{O}$ is a function of seawater density (e.g. Lynch-Stieglitz et al., 1999), and as G. truncatulinoides in particular was found to capture intermediate depth density (LeGrande et al., 2004), we have generated a reconstruction of pycnocline depth variability for the central Walvis Ridge, which we consider to be a paleo proxy for the presence of Agulhas rings/AL.

In this view, more AL reaches the west flank of the Cape Basin as MIS 6 draws to its end, and the influence is maximal right at T-II, likely higher than observed in the modern ocean (Table 1, Fig. 2b). The bimodal distribution of samples from $\sim 143$ to $130 \mathrm{kaBP}$, with clusters of values with low- $\delta^{18} \mathrm{O}$, is suggestive of more frequent low-density conditions captured in the foraminiferal geochemistry. This signal can be interpreted as the passage of more Agulhas rings, or of larger and more stable ones, that linger over the core site for longer. Both possibilities point to a stronger AL. Still, the latter seems corroborated by another finding: rings of greater size and stability have been connected to larger variability in the position of the Agulhas retroflection (van Sebille et al., 2009). This scenario is particularly plausible at times of climate shift such as T-II, when the system of fronts south of Africa was supposedly more dynamic, likely due to changes in the wind field (Hays et al., 1976; Bé and Duplessy, 1976; Bard and Rickaby, 2009).

We compare the timing of our observations to the published records of Agulhas leakage fauna (a proxy for AL) from the eastern Cape Basin, of Peeters et al. (2004) and Martínez-Méndez et al. (2010) (Fig. 2b). For this purpose, we rendered the age of the records of Peeters et al. (2004) and Martínez-Méndez et al. (2010) compatible with the chronology of our core, by aligning the respective benthic $\delta^{18} \mathrm{O}$ curves to the LR04 stack. The remarkable agreement between our variability record and the AL proxies answers the question whether the AL peak at T-II penetrated the South Atlantic circulation. Furthermore, the phenomenon took prominence in our record between $\sim 142$ and $138 \mathrm{ka}$ BP, during maximum glacial conditions. This points to a reaction of the Southern Hemisphere, in terms of thermocline warming and enhanced AL, coherent with the bipolar seesaw mechanism that marked the termination, as recently reformulated by Cheng et al. (2009) and Denton et al. (2010).

While we can assume that the heat and salt associated with AL observed at the central Walvis Ridge have been incorporated into the subtropical gyre circulation, it does not directly follow that those waters have made it to the North Brazil Current, and therefore into the North Atlantic. High-resolution ocean models showed that changes in the amount of $\mathrm{AL}$ in the Cape Basin do not directly lead to changes in the amount of Indian Ocean water crossing the Equator in the Atlantic (Biastoch et al., 2009; Biastoch and Böning, 2013). Instead, the heat and salt could just have recirculated in the Southern Hemisphere supergyre (e.g. Gordon et al., 1992; Speich et al., 2007).

However, there is modelling evidence that the heat and salt from AL do not have to reach the North Atlantic in order to impact the Atlantic meridional overturning circulation (AMOC) there. In high-resolution ocean models, the salt flux of the North Brazil Current (Biastoch et al., 2008), as well as the intensity of the AMOC (Biastoch and Böning, 2013), seem to be related to AL strength.

Therefore, even if little of the extra AL had made it into the North Atlantic, it could still have imposed an effect on the strength of the AMOC. Authors such as Weijer et al. (2002) have shown that the strength of the AMOC is, to a large extent, determined by the pressure gradient between the southern and northern Atlantic. Increased AL in the South Atlantic, beyond the Cape Basin, could change the meridional density and hence pressure gradients, and thereby the AMOC strength. Furthermore, van Sebille and van Leeuwen (2007) found that Agulhas rings in the South Atlantic Ocean can radiate some of their energy to the North Atlantic, even if no mass is transported across the Equator. In that idealized 
model, that energy might then be used in the North Atlantic to accelerate the AMOC.

In other words, our core on the central Walvis Ridge likely witnessed the AL resumption during T-II, thus lending important support to the idea of its central role in restoring the intensified interglacial mode of the conveyor belt (Gordon et al., 1992; Berger and Wefer, 1996; Weijer et al., 2002; Knorr and Lohmann, 2003). In perspective, we suggest that there is scope for further application of the methodology here presented at this location, in particular to unravel the timing of $\mathrm{AL}$ entering the AMOC during the last deglaciation, to address questions as to how the South Atlantic acted during the well-established succession of Older Dryas, BøllingAllerød and Younger Dryas events that lead to the present warm climate.

\section{Conclusions}

We have presented a novel application for the seldomutilized analysis of isotopes in individual foraminifera. After preliminary assessment of the extent of sediment mixing processes, the method can conveniently be utilized to unravel paleoceanographic aspects beyond the average state of physicochemical quantities, in particular to test hypotheses relative to mixing of water masses with different characteristics.

In this study, we assessed the paleo-variability in the $\delta^{18} \mathrm{O}$ of a thermocline-dwelling taxon, suggesting substantially higher density anomalies in the South Atlantic Gyre, around the penultimate termination. Corroborated by a highresolution assimilative ocean circulation model, we are able to interpret such anomalies as the passage of Agulhas rings, or other leakage features, spawning from the Agulhas Current retroflection. The evidence we present fills a gap between the AL increase recorded around T-II at the interface between the Indian and the Atlantic oceans, and its incorporation downstream into the South Atlantic gyre, and hence also the supergyre. Such a connection is necessary to bolster the current hypothesis of the primary role played by the AL, in the transition from superficial glacial to vigorous interglacial AMOC, either as an active mechanism or rather as a passive feedback trigged by changes in Southern Hemisphere wind fields.

Acknowledgements. P. Scussolini and J. V. Durgadoo were funded by the European Community's Seventh Framework Programme FP7/2007-2013 - Marie-Curie ITN, under grant agreement no. 238512, GATEWAYS project. E. van Sebille was supported by Australian Research Council grant no. DE130101336.

We thank Geert-Jan Brummer for the availability of core 64PE174P13; Frank Peeters, Gregor Knorr, Conor Purcell and Arne Biastoch for the fruitful discussions and ideas; and Brett Metcalfe for support with the revision of the manuscript. This is publication no. A438 from the Bjerknes Centre for Climate Research.

\section{References}

Arhan, M., Speich, S., Messager, C., Dencausse, G., Fine, R., and Boye, M.: Anticyclonic and cyclonic eddies of subtropical origin in the subantarctic zone south of Africa, J. Geophys. Res., 116, C11004, doi:10.1029/2011jc007140, 2011.

Bard, E.: Paleoceanographic implications of the difference in deepsea sediment mixing between large and fine particles, Paleoceanography, 16, 235-239, doi:10.1029/2000pa000537, 2001.

Bard, E. and Rickaby, R. E. M.: Migration of the subtropical front as a modulator of glacial climate, Nature, 460, 380-383, doi:10.1038/nature08189, 2009

Bé, A. W. and Duplessy, J. C.: Subtropical convergence fluctuations and quaternary climates in the middle latitudes of the Indian ocean, Science, 194, 419-422, doi:10.1126/science.194.4263.419, 1976.

Beal, L. M., De Ruijter, W. P. M., Biastoch, A., and Zahn, Ra.: On the role of the Agulhas system in ocean circulation and climate, Nature, 472, 429-436, doi:10.1038/nature09983, 2011.

Berger, W. H. and Wefer, G.: Expeditions into the past: Paleoceanographic studies in the South Atlantic, in: The South Atlantic: Present and Past Circulation, edited by: Wefer, G., Berger, W. H., Siedler, G., and Webb, D. J., Springer, 363-410, doi:10.1007/978-3-642-80353-6_21, 1996.

Biastoch, A. and Böning, C. W.: Anthropogenic impact on Agulhas leakage, Geophys. Res. Lett., 40, 1138-1143, doi:10.1002/grl.50243, 2013.

Biastoch, A., Boning, C. W., and Lutjeharms, J. R. E.: Agulhas leakage dynamics affects decadal variability in Atlantic overturning circulation, Nature, 456, 489-492, doi:10.1038/nature07426, 2008.

Biastoch, A., Boning, C. W., Schwarzkopf, F. U., and Lutjeharms, J. R. E.: Increase in Agulhas leakage due to poleward shift of Southern Hemisphere westerlies, Nature, 462, 495-498, doi:10.1038/nature08519, 2009.

Billups, K. and Spero, H. J.: Relationship between shell size, thickness and stable isotopes in individual planktonic foraminifera from two Equatorial Atlantic cores, The Journal of Foraminiferal Research, 25, 24-37, doi:10.2113/gsjfr.25.1.24, 1995.

Boebel, O., Rossby, T., Lutjeharms, J., Zenk, W., and Barron, C.: Path and variability of the Agulhas Return Current, Elsevier, Kidlington, ROYAUME-UNI, 22 pp., doi:10.1016/S09670645(02)00377-6, 2003.

Byrne, D. A., Gordon, A. L., and Haxby, W. F.: Agulhas Eddies: A Synoptic View Using Geosat ERM Data, J. Phys. Oceanogr., 25, 902-917, doi:10.1175/15200485(1995)025<0902:aeasvu>2.0.co;2, 1995.

Cheng, H., Edwards, R. L., Broecker, W. S., Denton, G. H., Kong, X., Wang, Y., Zhang, R., and Wang, X.: Ice Age Terminations, Science, 326, 248-252, doi:10.1126/science.1177840, 2009.

Clement, A. C. and Gordon, A. L.: The absolute velocity field of Agulhas eddies and the Benguela Current, J. Geophys. Res.Oceans, 100, 22591-22601, doi:10.1029/95jc02421, 1995.

Dencausse, G., Arhan, M., and Speich, S.: Routes of Agulhas rings in the southeastern Cape Basin, Deep Sea Res. Part I, 57, 1406$1421,2010$. 
Denton, G. H., Anderson, R. F., Toggweiler, J. R., Edwards, R. L., Schaefer, J. M., and Putnam, A. E.: The Last Glacial Termination, Science, 328, 1652-1656, doi:10.1126/science.1184119, 2010.

Doglioli, A. M., Veneziani, M., Blanke, B., Speich, S., and Griffa, A.: A Lagrangian analysis of the Indian-Atlantic interocean exchange in a regional model, Geophys. Res. Lett., 33, L14611, doi:10.1029/2006g1026498, 2006.

Dong, S., Garzoli, S., and Baringer, M.: The Role of Interocean Exchanges on Decadal Variations of the Meridional Heat Transport in the South Atlantic, J. Phys. Oceanogr., 41, 1498-1511, doi:10.1175/2011jpo4549.1, 2011.

Donners, J. and Drijfhout, S. S.: The Lagrangian View of South Atlantic Interocean Exchange in a Global Ocean Model Compared with Inverse Model Results, J. Phys. Oceanogr., 34, 1019-1035, doi:10.1175/1520-0485(2004)034<1019:TLVOSA>2.0.CO;2, 2004.

Durgadoo, J. V., Loveday, B. R., Reason, C. J. C., Penven, P., and Biastoch, A.: Agulhas leakage predominantly responds to the southern hemisphere westerlies, J. Phys. Oceanogr., 43, 21132131, doi:10.1175/JPO-D-13-047.1, 2013.

Erez, J. and Honjo, S.: Comparison of isotopic composition of planktonic foraminifera in plankton tows, sediment traps and sediments, Palaeogeogr. Palaeocli., Palaeoecol., 33, 129-156, 1981.

Flores, J.-A., Gersonde, R., and Sierro, F. J.: Pleistocene fluctuations in the Agulhas Current retroflection based on the calcareous plankton record, Mar. Micropaleontol., 37, 1-22, 1999.

Franzese, A. M., Hemming, S. R., Goldstein, S. L., and Anderson, R. F.: Reduced Agulhas Leakage during the Last Glacial Maximum inferred from an integrated provenance and flux study, Earth Planet. Sci. Lett., 250, 72-88, 2006.

Ganssen, G., Peeters, F., Metcalfe, B., Anand, P., Jung, S., Kroon, D., and Brummer, G.-J.: Quantifying sea surface temperature ranges of the Arabian Sea for the past 20000 years, Clim. Past Discuss., 6, 2795-2814, doi:10.5194/cp-7-1337-2011, 2011.

Gordon, A. L. and Haxby, W. F.: Agulhas Eddies Invade the South Atlantic: Evidence From Geosat Altimeter and Shipboard Conductivity-Temperature-Depth Survey, J. Geophys. Res., 95, 3117-3125, doi:10.1029/JC095iC03p03117, 1990.

Gordon, A. L., Weiss, R. F., Smethie Jr., W. M., and Warner, M. J.: Thermocline and Intermediate Water Communication Between the South Atlantic and Indian Oceans, J. Geophys. Res., 97, 7223-7240, doi:10.1029/92jc00485, 1992.

Giulivi, C. F. and Gordon, A. L.: Isopycnal displacements within the cape basin thermocline as revealed by the hydrographic data archive, Deep-Sea Res. Part I, 53, 1285-1300, doi:10.1016/j.dsr.2006.05.011, 2006.

Hall, C. and Lutjeharms, J. R. E.: Cyclonic eddies identified in the cape basin of the south atlantic ocean, J. Mar. Syst., 85, 1-10, doi:10.1016/j.jmarsys.2010.10.003, 2011.

Hays, J. D., Lozano, J. A., Shackleton, N., and Irving, G.: Reconstruction of the Atlantic and Western Indian Ocean sectors of the 18,000 B.P. Antarctic Ocean, in: Geol. Soc. Amer. Mem, edited by: Cline, R. M. and Hays, J. D., Geol. Soc. Am., Boulder, 337372, 1976.

Hemleben, C., Spindler, M., Breitinger, I., and Deuser, W. G.: Field and laboratory studies on the ontogeny and ecology of some globorotaliid species from the sargasso sea off bermuda, J. Foraminiferal Res., 15, 254-272, 1985.

Hutson, W. H.: The Agulhas Current During the Late Pleistocene: Analysis of Modern Faunal Analogs, Science, 207, 64-66, doi:10.1126/science.207.4426.64, 1980.

Killingley, J. S., Johnson, R. F., and Berger, W. H.: Oxygen and carbon isotopes of individual shells of planktonic foraminifera from Ontong-Java plateau, equatorial pacific, Palaeogeogr. Palaeocli. Palaeoecol., 33, 193-204, doi:10.1016/0031-0182(81)90038-9, 1981.

Knorr, G. and Lohmann, G.: Southern Ocean origin for the resumption of Atlantic thermohaline circulation during deglaciation, Nature, 424, 532-536, doi:10.1038/nature01855, 2003.

Koutavas, A., deMenocal, P. B., Olive, G. C., and Lynch-Stieglitz, J.: Mid-Holocene El Niño Southern Oscillation (ENSO) attenuation revealed by individual foraminifera in eastern tropical $\mathrm{Pa}$ cific sediments, Geology, 34, 993-996, doi:10.1130/g22810a.1, 2006.

Leduc, G., Vidal, L., Cartapanis, O., and Bard, E.: Modes of eastern equatorial Pacific thermocline variability: Implications for ENSO dynamics over the last glacial period, Paleoceanography, 24, PA3202, doi:10.1029/2008pa001701, 2009.

LeGrande, A. N., Lynch-Stieglitz, J., and Farmer, E. C.: Oxygen isotopic composition of Globorotalia truncatulinoides as a proxy for intermediate depth density, Paleoceanography, 19, PA4025, doi:10.1029/2004PA001045, 2004.

Lisiecki, L. E. and Raymo, M. E.: A Pliocene-Pleistocene stack of 57 globally distributed benthic delta180 records, Paleoceanography, 20, PA1003, doi:10.1029/2004pa001071, 2005.

Lohmann, G. P. and Schweitzer, P. N.: Globorotalia Truncatulinoides' Growth and Chemistry as Probes of the Past Thermocline: 1. Shell Size, Paleoceanography, 5, 55-75, doi:10.1029/PA005i001p00055, 1990.

Lončarić, N., Peeters, F. J. C., Kroon, D., and Brummer, G.-J. A.: Oxygen isotope ecology of recent planktic foraminifera at the central Walvis Ridge (SE Atlantic), Paleoceanography, 21, PA3009, doi:10.1029/2005PA001207, 2006.

Lončarić, N., van Iperen, J., Kroon, D., and Brummer, G.-J. A.: Seasonal export and sediment preservation of diatomaceous, foraminiferal and organic matter mass fluxes in a trophic gradient across the se atlantic, Prog. Oceanogr., 73, 27-59, 2007.

Lutjeharms, J. R. E.: The Agulhas Current, Springer, Berlin, Germany, doi:10.2989/18142320609504223, 2006.

Lutjeharms, J. R. E. and Cooper, J.: Interbasin leakage through Agulhas Current filaments, Deep-Sea Res. Part I, 43, 213-238, doi:10.1016/0967-0637(96)00002-7, 1996.

Lynch-Stieglitz, J., Curry, W. B., and Slowey, N.: A Geostrophic Transport Estimate for the Florida Current from the Oxygen Isotope Composition of Benthic Foraminifera, Paleoceanography, 14, 360-373, doi:10.1029/1999pa900001, 1999.

Madec, G.: NEMO ocean engine. Note du Pole de modeisation de l'Institut Pierre-Simon Laplace No. 27, ISSN No. 12, 215 pp., 2008.

Marino, G., Zahn, R., Ziegler, M., Purcell, C., Knorr, G., Hall, I. R., Ziveri, P., and Elderfield, H.: Agulhas salt-leakage oscillations during abrupt climate changes of the late pleistocene, Paleoceanography, 28, 599-606, doi:10.1002/palo.20038, 2013.

Martínez-Méndez, G., Zahn, R., Hall, I. R., Peeters, F. J. C., Pena, L. D., Cacho, I., and Negre, C.: Contrasting multiproxy 
reconstructions of surface ocean hydrography in the Agulhas Corridor and implications for the Agulhas Leakage during the last 345,000 years, Paleoceanography, 25, PA4227, doi:10.1029/2009pa001879, 2010.

Matano, R. P. and Beier, E. J.: A kinematic analysis of the Indian/Atlantic interocean exchange, Deep Sea Res. Part-II, 50, 229-249, doi:10.1016/S0967-0645(02)00395-8, 2003.

Mortyn, P. G. and Charles, C. D.: Planktonic foraminiferal depth habitat and $\delta^{18} \mathrm{O}$ calibrations: Plankton tow results from the Atlantic sector of the Southern Ocean, Paleoceanography, 18, 1037, doi:10.1029/2001pa000637, 2003.

Mulitza, S., Dürkoop, A., Hale, W., Wefer, G., and Niebler, H. S.: Planktonic foraminifera as recorders of past surfacewater stratification, Geology, 25, 335-338, doi:10.1130/00917613(1997)025<0335:PFAROP>2.3.CO;2, 1997.

Olson, D. B. and Evans, R. H.: Rings of the Agulhas current, Deep Sea Res. Part A., 33, 27-42, doi:10.1016/0198-0149(86)901068, 1986.

Peeters, F. J. C., Acheson, R., Brummer, G.-J. A., de Ruijter, W. P. M., Schneider, R. R., Ganssen, G. M., Ufkes, E., and Kroon, D.: Vigorous exchange between the Indian and Atlantic oceans at the end of the past five glacial periods, Nature, 430, 661-665, doi:10.1038/nature02785, 2004.

Richardson, P. L.: Agulhas leakage into the Atlantic estimated with subsurface floats and surface drifters, Deep Sea Res. Part I, 54, 1361-1389, doi:10.1016/j.dsr.2007.04.010, 2007.

Schouten, M. W., de Ruijter, W. P. M., van Leeuwen, P. J., and Lutjeharms, J. R. E.: Translation, decay and splitting of Agulhas rings in the southeastern Atlantic Ocean, J. Geophys. Res., 105, 21913-21925, doi:10.1029/1999jc000046, 2000.

Scussolini, P. and Peeters, F. J. C.: A record of the 460 thousand years of upper ocean stratification from the central Walvis Ridge, South Atlantic, Paleoceanography, 28, 426-439, doi:10.1002/palo.20041, 2013.

Smith, C. R. and Rabouille, C.: What controls the mixed-layer depth in deep-sea sediments? The importance of poc flux, Limnol. Oceanogr, 47, 418-426, doi:10.4319/lo.2002.47.2.0418, 2002.

Souza, J. M. A. C., de Boyer Montègut, C., Cabanes, C., and Klein, P.: Estimation of the Agulhas ring impacts on meridional heat fluxes and transport using ARGO floats and satellite data, Geophys. Res. Lett., 38, L21602, doi:10.1029/2011g1049359, 2011.

Speich, S., Blanke, B., and Cai, W.: Atlantic meridional overturning circulation and the Southern Hemisphere supergyre, Geophys. Res. Lett., 34, L23614, doi:10.1029/2007g1031583, 2007.
Thirumalai, K., Partin, J. W., Jackson, C. S., and Quinn, T. M.: Statistical constraints on el niño southern oscillation reconstructions using individual foraminifera: A sensitivity analysis, Paleoceanography, 28, 1-12, doi:10.1002/palo.20037, 2013.

Trauth, M. H., Sarnthein, M., and Arnold, M.: Bioturbational mixing depth and carbon flux at the seafloor, Paleoceanography, 12, 517-526, doi:10.1029/97pa00722, 1997.

Treguier, A. M., Boebel, O., Barnier, B., and Madec, G.: Agulhas eddy fluxes in a $1 / 6^{\circ}$ Atlantic model, Deep-Sea Res. II, 50, 251 280, doi:10.1016/S0967-0645(02)00396-X, 2003.

van Aken, H. M., van Veldhoven, A. K., Veth, C., de Ruijter, W. P. M., van Leeuwen, P. J., Drijfhout, S. S., Whittle, C. P., and Rouault, M.: Observations of a young Agulhas ring, Astrid, during MARE in March 2000, Deep Sea Res. ParT-II, 50, 167-195, doi:10.1016/S0967-0645(02)00383-1, 2003.

van Sebille, E. and van Leeuwen, P. J.: Fast Northward Energy Transfer in the Atlantic due to Agulhas Rings, J. Phys. Oceanogr., 37, 2305-2315, doi:10.1175/jpo3108.1, 2007.

van Sebille, E., Barron, C. N., Biastoch, A., van Leeuwen, P. J., Vossepoel, F. C., and de Ruijter, W. P. M.: Relating Agulhas leakage to the Agulhas Current retroflection location, Ocean Sci., 5, 511-521, doi:10.5194/os-5-511-2009, 2009.

van Sebille, E., van Leeuwen, P. J., Biastoch, A., and de Ruijter, W. P. M.: On the fast decay of Agulhas rings, J. Geophys. Res., 115, C03010, doi:10.1029/2009jc005585, 2010a.

van Sebille, E., van Leeuwen, P. J., Biastoch, A., and de Ruijter, W. P. M.: Flux comparison of Eulerian and Lagrangian estimates of Agulhas leakage: A case study using a numerical model, DeepSea Res. I, 57, 319-327, doi:10.1016/j.dsr.2009.12.006, 2010b.

van Sebille, E., Johns, W. E., and Beal, L. M.: Does the vorticity flux from Agulhas rings control the zonal pathway of NADW across the South Atlantic?, J. Geophys. Res., 117, C05037, doi:10.1029/2011jc007684, 2012.

Weijer, W., De Ruijter, W. P. M., and Dijkstra, H. A.: Stability of the Atlantic Overturning Circulation: Competition between Bering Strait Freshwater Flux and Agulhas Heat and Salt Sources, J. Phys. Oceanogr., 31, 2385-2402, doi:10.1175/15200485(2001)031<2385:SOTAOC>2.0.CO;2, 2001.

Weijer, W., De Ruijter, W. P. M., Sterl, A., and Drijfhout, S. S.: Response of the Atlantic overturning circulation to South Atlantic sources of buoyancy, Global Planet. Change, 34, 293-311, doi:10.1016/S0921-8181(02)00121-2, 2002. 